\title{
SKIRTINGŲ REABILITACIJOS METODŲ POVEIKIS VAIKŲ, SERGANČIUU CEREBRINIU PARALYŽIUMI, MOTORINĖMS FUNKCIJOMS BEI EISENAI
}

\author{
Giedrẻ Juškẻnienè ${ }^{1}$, Aurelija Šidlauskienè ${ }^{1}$, Juozas Raistenskis ${ }^{1}$, Jurgita Žižienè2 \\ Kristina Daunoravičiené ${ }^{2}$ \\ ${ }^{I}$ Vilniaus universiteto Medicinos fakulteto Sveikatos mokslu institutas, \\ ${ }^{2}$ Vilniaus Gedimino technikos universitetas
}

\begin{abstract}
Raktažodžiai: vaikai, cerebrinis paralyžius, eisenos analizè, motorinès funkcijos.

Santrauka

Cerebrinis paralyžius (CP) susijęs su besivystančių smegenų pažeidimu ir apima grupę pastovių judejjimo ir laikysenos vystymosi sutrikimų, lemniačių kasdienio aktyvumo apribojimą $[1,2]$. Ši liga dažniausiai pasireiškia apatinių galūnių silpnumu bei sutrikusia eisena $[3,4]$. Tai viena iš dažniausių neịgalumo priežasčiu vaikysteje [5]. Kineziterapija yra pagrindinè vaikų, sergančių CP, reabilitacijos procedūra, kurios metu stiprinant galūnių raumenis koreguojama eisena bei pagerejja vaikščiojimo funkcija, tačiau iki šiol nèra sukurta standartinių CP reabilitacijos programų [4]. Literatūroje nurodoma, kad galima nustatyti eisenos nuokrypio ir klinikinès išraiškos sąsajas, identifikuojant atskiras eisenos ciklo fazes. Šių žinių pritaikymas praktikoje galètų lemti geresnį supratimą apie eisenos sutrikimų patofiziologiją bei pagerinti individualaus gydymo plano sudarymą [6].
\end{abstract}

\section{Ivadas}

Cerebrinis paralyžius (CP) yra susijęs su besivystančių smegenų pažeidimu, kuris yra viena iš dažniausių neigalumo priežasčių vaikysteje [2,5]. CP tai neprogresuojanti neurologinè būklè, kuri pasireiškia raumenų tonuso, judesių bei motorinès funkcijos sutrikimais, kurie intensyveja nuo proksimalinès link distalinès apatinès galūnès dalies (t.y. didžiausias pažeidimas čiurnoje) [2,7]. Raumenų silpnumas yra vienas iš labiausiai išreikštų vaikų CP simptomų [8]. Sutrikusi stambioji bei smulkioji motorika, iskaitant jutimu, percepcijos, pažintinių funkcijų, bendravimo, kalbos sutrikimus, yra būdingi CP bruožai. Epilepsija bei antriniai skeletoraumenu sistemos sutrikimai taip pat dažnos CP problemos. Motorikos sutrikimas sergant $\mathrm{CP}$ pasireiškia spastiškumu, distonija, kontraktūromis, kaulu deformacijomis, sutrikusia koordinacija, selektyvinès motorinès kontrolès praradimu bei raumenų silpnumu. CP sergantiems vaikams būdingas visas spektras funkcinių motorinių sutrikimų bei patologinès eisenos modelių. Nustatyta, kad patologine eisena lemia didesnes energijos sąnaudas èjimo metu bei suprastejjusią vaikščiojimo funkciją [9]. Prasta eisena lemia sumažejusui mobilumą ir neigalumą, o tai gali sukelti raumenų silpnumą bei pusiausvyros pablogèjimą, todèl eisenos kokybès vertinimas gali būti svarbus šiems pacientams [10]. Vaikams, sergantiems $\mathrm{CP}$, būdingas sumažèjęs èjimo greitis, kuris neigiamai veikia jų dalyvavimą bendruomenèje bei gyvenimo kokybę $[4,11]$. Iprasti CP reabilitacijos tikslai - tai valingų, aktyvių judesių, reikalingų funkcinei veiklai (pvz., vaikščiojimo), lavinimas [7]. Problema ta, kad iki šiol trūksta reabilitacijos intervencijų, eisenos greičio didinimui, efektyvumo įrodymų [11]. Daugybe atliktų studijų rodo, kad eisenos treniravimas gali pagerinti vaikų, sergančių $C P$, vaikščiojimo galimybes, tačiau šiems pokyčiams įtakos turintys veiksniai lieka neaiškūs [3].

Tyrimo tikslas - išsiaiškinti skirtingų reabilitacijos metodų įtaką vaikų, sergančių cerebriniu paralyžiumi, motorinėms funkcijoms bei eisenos parametrams. Uždaviniai: atrinkti ir išanalizuoti mokslines publikacijas, kuriose pristatomi rezultatai apie reabilitacijos metodų (programų) efektyvumą vaikų, sergančių cerebriniu paralyžiumi, motorinèms funkcijoms bei eisenos parametrams.

\section{Tyrimo medžiaga ir metodai}

Straipsnyje apžvelgiami naujausi moksliniai tyrimai, kuriais remiantis analizuojamas skirtingų reabilitacijos metodų (programų) poveikis vaikų, sergančių $\mathrm{CP}$, motorinèms funkcijoms ir eisenos parametrams. Literatūros paieška atlikta 2021-02-10, naudojant PubMed duomenų bazès paieškos sistemą. Paieškai atlikti pasitelkti šie raktažodžiai ir jų deriniai: children, cerebral palsy, gait analysis, motor 
function. Literatūros šaltinių ittraukimo ir atmetimo kriterijai pateikiami 1 lentelèje.

\section{Rezultatai}

Raumenų silpnumas yra vienas iš labiausiai išreikštų vaikų CP simptomų [8]. CP skirstomas ị unilateralinị ir bilateralinį. Unilateraliniam CP būdingas vienos kūno pusès galūnių pažeidimas, o bilateraliniam - abiejų pusių [1]. Pastebèta, kad CP sergantiems vaikams būdinga laikysenos ir eisenos nuokrypių įvairovė, kartu ir visas spektras funkcinių motorinių sutrikimų bei patologinès eisenos modelių $[1,9]$. $\mathrm{Be}$ to, vaikų, sergančiu dipleginiu $\mathrm{CP}$, laikysenos nuokrypių įvairové žymiai didesnè nei vaikų, sergančių unilateraliniu CP. Literatūroje aprašoma daugybe dažniausiai pasitaikančių dipleginio CP eisenos modelių klasifikacijos schemų [1].

Vaikų, sergančių cerebriniu paralyžiumi, eisenos modeliai. S. Armand su bendraautoriais (2016) nurodo, kad dažniausiai pasitaikantys CP sergančiujų eisenos modeliai skirstomi ị spastinị hemipleginị (krentančios pèdos, arklio eisena su skirtingomis kelio sąnario pozicijomis) ir spastinị dipleginị (tikroji arklio, šuoliuojanti, eisena sulenktais keliais) [12]. Tarptautinèje literatūroje dažniausiai minima J. Rodda ir H. Graham klasifikacija, paremta sagitalinès plokštumos kinematika, atsižvelgiant ị čiurną, kelị, klubą ir dubenį. M. Domagalska ir bendraautoriai (2019) nurodo, kad skiriami 4 dipleginio CP eisenos modeliai: tikroji arklio (angl. true equinus), šuoliuojanti (angl. jump gait), tariamoji arklio (angl. apparent equinus) ir eisena sulenktais keliais (angl. crouch gait). Autore taip pat pastebi, kad dauguma eisenos modelių klasifikacijos sistemų remiasi tik apatinių galūnių kinematikos nuokrypiais sagitalinèje plokštumoje, visiškai neatsižvelgiant ị dubens ir liemens kinematiką [1]. Vienas iš dažnesnių patologinių eisenos modelių - eisena sulenktais keliais (angl. crouch gait) lemia didesnes energijos sąnaudas ejjimo metu bei suprastejjusią vaikščiojimo funkciją [9].

Cerebriniu paralyžiumi sergančių pacientų klinikinè eisenos analizè. Klinikinè eisenos analizè (KEA) leidžia identifikuoti eisenos sutrikimus, suprasti priežastis bei jas koreguoti. KEA metu apdorojamas didelis kiekis kiekybinių eisenos charakteristikos duomenų, tokių kaip vaizdas, kinematika, kinetika, elektromiografija bei plantarinis spaudimas. Siekiant teisingai interpretuoti KEA duomenis bei gebèti atskirti pirminį eisenos sutrikimą nuo kompensacinio mechanizmo, būtina eisenos nukrypimus susieti su klinikiniais radiniais. KEA neparodo tiesiogiai, kaip gydyti CP pacientą, tačiau objektyviai identifikuoja eisenos sutrikimus ir pagilina supratimą apie jų priežastis. CP sergančių pacientų eisenos korekcijai naudojama daugybė gydymo būdų. Paprastai gydymo tikslas būna išvengti antrinių komplikacijų, atkurti sverto funkciją ir išsaugoti raumenų jègą. Klinikinio eisenos tyrimo metu vertinami gydymo rezultatai [12].

Skirtingų reabilitacijos metodų poveikis vaikų, sergančių CP, motorinėms funkcijoms bei eisenai. Vaikams, sergantiems CP, būdingas sumažejęs èjimo greitis, kuris neigiamai veikia jų dalyvavimą bendruomenèje bei gyvenimo kokybę. Problema ta, kad iki šiol trūksta eisenos greičio didinimo reabilitacijos intervencijų efektyvumo įrodymų. Pastebeta, kad eisenos treniravimas yra labiausiai efektyvi priemonè, siekiant padidinti CP sergančių vaikų eisenos greiti [11].

1 lentelè. Literatūros šaltiniu įtraukimo ir atmetimo kriterijai

* GMFCS (angl. Gross motor function classification system) - Stambiosios motorikos funkcijos klasifikacijos sistema

\begin{tabular}{|c|c|c|}
\hline Kriterijus & İtraukimo & Atmetimo \\
\hline Laikotarpis & $20160101-20210210$ & Anksčiau paskelbti straipsniai \\
\hline Kalba & Anglų, lietuvių & Kitos kalbos \\
\hline Tyrimų tipai & $\begin{array}{l}\text { Stebejjimo analitiniai tyrimai: korelia- } \\
\text { ciniai, momentiniai, atvejo ir kontro- } \\
\text { lès, kohortiniai }\end{array}$ & $\begin{array}{l}\text { Kokybiniai tyrimai } \\
\text { Kitokie nei stebejimo analitiniai tyrimai }\end{array}$ \\
\hline \multicolumn{3}{|l|}{ Tyrimo dalyviai: } \\
\hline - amžius & 2-18 metų vaikai & $\begin{array}{l}\text { jaunesni nei } 2 \text { metų vaikai ir asmenys, vyresni nei } \\
18 \text { metų }\end{array}$ \\
\hline - diagnozè & cerebrinis paralyžius & nediagnozuotas cerebrinis paralyžius \\
\hline - GMFCS* lygis & I - III lygis & IV - V lygis \\
\hline Analizuojami veiksniai & $\begin{array}{l}\text { Raumenų jėga, tonusas, sąnarių ju- } \\
\text { desių amplitudės, eisenos parametrai } \\
\text { (eisenos nuokrypio indeksas, žingsnių } \\
\text { simetriškumas, dažnis, žingsnio ilgis, } \\
\text { greitis) }\end{array}$ & $\begin{array}{l}\text { Neanalizuojama raumenų jèga, tonusas, sąnarių } \\
\text { judesių amplitudès, eisenos parametrai }\end{array}$ \\
\hline Publikacijų šaltinis & PubMed & Kitos duomenų bazès \\
\hline
\end{tabular}




\section{8}

Nors yra atlikta nemažai studijų, rodančių teigiamą treniruočiu su bėgtakiu poveikị CP sergančių vaikų eisenai, tačiau kokybinių tyrimų apie tokių treniruočių ịtaką nėra daug. Y. Han ir C. Yun (2020) tyrimo tikslas buvo išanalizuoti treniruočių ant bėgtakio poveikị vaikų, sergančių $C P$, specifiniams eisenos parametrams (ejjimo ištvermei, greičiui, galūnès palaikymo laikui (angl. limb support time), žingsnių dažniui bei ilgiui). Rezultatai parodè, kad treniruotè su bėgtakiu yra efektyvi priemone eisenos ištvermei, greičiui, galūnès palaikymo laikui, žingsnių dažniui bei ilgiui [13].

A. Booth ir kolegos (2018) taip pat pažymi, kad funkcinè eisenos treniruote - tai saugi, paprasta bei efektyvi priemonè pagerinti èjimo funkciją. Ši priemonè turi didesnị poveikị eisenos greičiui, nei įprasta kineziterapija. Funkcinis eisenos treniravimas taip pat turi teigiamą poveiki èjimo ištvermei bei su ejimu susijusiai stambiajai motorikai [14]. Tuo tarpu, raumenu jëgos treniravimas, netgi tinkamai dozuojamas, nèra efektyvi priemonè ejimo greičiui didinti [11].

Nors naujausi tyrimai rodo, kad funkcinès jègos treniruotès gali padidinti ankstyvo amžiaus $\mathrm{CP}$ sergančių vaikų jëgą bei funkcinị pajëgumą, tačiau apie poveikị specifiniams eisenos parametrams nebuvo pranešta. L. Oudenhoven ir bendraautoriai (2019) atliko tyrimą ir nustatè, kad po funkcinès jẻgos treniruotès gali pagerèti eisenos kinematika, tačiau didžiausią įtaką tam turi greitis. Atlikto tyrimo autoriai taip pat atkreipè dèmesị, kad pagerèjimas gali likti nepastebètas vertinant eiseną tik komfortabilaus èjimo greičio metu [8].

Vikrumo lavinimas, elektromiografijos grịžtamojo ryšio prietaiso naudojimas bei viso kūno vibracija atskirose studijose taip pat turejo teigiamą poveikị èjimo greičiui, tačiau reikalingi tolesni tyrimai [11]. A. Booth su bendraautoriais (2018) taip pat teigia, kad virtuali realybe bei grižtamojo ryšio naudojimas funkcinès eisenos treniruotès metu ko gero padidintų motyvaciją bei pagerintų rezultatus [14].

Motorikos pažeidimas bei apsunkintas valingas raumenu valdymas, būdingas cerebriniu paralyžiumi sergančiųų populiacijai, pasireiškia sutrikusia neuroraumenine apatinių galūniu kontrole. Iprastiniai CP reabilitacijos tikslai - tai valingų, aktyvių judesių, reikalingų funkcinei veiklai (pvz., vaikščiojimas), lavinimas [7]. Manoma, kad apatinių galūnių funkcijos tobulejimas siejasi su geresne gyvenimo kokybe [4]. Daugybė atliktų studijų rodo, kad eisenos treniravimas gali pagerinti vaikų, sergančių $\mathrm{CP}$, vaikščiojimo galimybes, tačiau šiems pokyčiams įtakos turintys veiksniai lieka neaiškūs. R. Hofmano ir jo kolegų (2018) atliktas tyrimas atskleidè, kad apatinių galūnių jègos pokyčiai gali būti susiję su tam tikro laipsnio eisenos greičio pokyčiais, stebimais po eisenos treniruočių. Atlikus šị tyrimą pastebèta, kad didesnis teigiamas eisenos treniruočių poveikis apatinių galūnių jègai gautas jaunesnių vaikų grupejje [3]. İrodyta, kad kineziterapi- jos pratimai su pasipriešinimu turi teigiamą poveikị raumenų jègos didejjimui bei motorinei funkcijai, tačiau jų ịtaka eisenai lieka neaiški. L. Garido ir bendraautorių (2019) atliktoje sisteminëje apžvalgoje pateikiamos išvados atskleidžia, kad rezistyvinè terapija gali turèti įtakos eisenos pagerèjimui, ypač greičio ir žingsnių dažnio parametrams [5].

Eisenos nuokrypio indeksas (ENI) yra svarbus rodiklis, atspindintis bendrą pacientų, sergančių spastiniu CP ir kitomis ligomis, eisenos sutrikimą. Eisenos nuokrypio indeksas apskaičiuojamas iš trimatès eisenos analizès metu gautų kinematinių duomenų. Nustatyta, kad kuo sunkesnis CP, tuo blogesnis ENI. Kai kurie atlikti tyrimai parodè, kad ENI koreliuoja su stambiosios motorikos funkcija, ịvertinta pagal Stambiosios motorikos funkcijos klasifikacijos sistemą (GMFCS) [10].

N. Matsunaga ir kolegos (2018) nustate, kad spastinio cerebrinio paralyžiaus klinikiniai parametrai (judesių amplitudès, raumenų jèga ir spastiškumas) yra susiję su eisenos nuokrypio indeksu. Nors tyrimo metu pastebètas ryšys tarp spastiniu CP sergančiųjų eisenos nuokrypio ir klinikinių požymių, praktikoje dažnai tai sudètinga įrodyti, net ir naudojant ịvairius galimus testus. Yra keletas atrankos testų, kurie atspindi paciento funkcines galimybes. Pavyzdžiui, eisenos greičio matavimas yra patikima priemonè $\mathrm{CP}$ sergančių pacientų eisenos pajègumui ịvertinti, o penkių kartų „sèsti-stoti“ testas atspindi funkcinę apatinių galūnių raumenų jègą ir pusiausvyrą [15]. Penkių kartų ,sèsti-stoti“ testas gali netiesiogiai parodyti paciento, sergančio spastiniu $\mathrm{CP}$, vaikščiojimo galimybes, kadangi jo rezultatai siejasi su funkcine raumenų jëga. Vis dellto, straipsnyje pažymima, kad nėra duomenų apie šio testo ryšį su eisenos greičiu bei ENI, vertinant pacientus, sergančius CP [10]. Prasta eisena lemia sumažèjusį mobilumą ir neiggalumą, o tai gali sukelti raumenų silpnumą bei pusiausvyros pablogèjimą, todèl eisenos kokybès vertinimas gali būti svarbus šiems pacientams [10].

Viena iš CP sergančių vaikštančių vaikų eisenos sutrikimo priežasčių yra sumažejjusi kelio tiesimo amplitudè. M. Fosdahl ir kolegos (2019) atliko tyrimą, norèdami išsiaiškinti kombinuotos kineziterapijos programos, kurią sudare tempimo bei progresyviniai rezistenciniai pratimai, akcentuoti i aktyvų kelio tiesimo didinimą, itaką vaikų su spastiniu CP eisenos funkcijai. Tyrime dalyvavo 37 vaikai, priklausantys I-III lygiui pagal Stambiosios motorikos vertinimo skalę (GMFCS), kurie atsitiktiniu būdu buvo suskirstyti ị dvi grupes. Intervencinei grupei $(\mathrm{n}=17) 16$ savaičių (3k./sav.) buvo taikyta kombinuota pratimų programa, ịskaitant hamstringu tempimą bei progresyvinius rezistencinius pratimus, akcentuojant apatinių galūnių treniravimą. Po to dar 16 savaičių taikyta palaikomoji programa (1k./sav.). Kontrolinei grupei buvo taikyta ịprastinè kineziterapijos programa. Eisena buvo 
vertinta trimate eisenos analizès sistema; kelio, klubo, dubens kinematika sagitalioje plokštumoje, žingsnio ilgis ir greitis, eisenos nuokrypio indeksas (angl. Gait Deviation Index, GDI), 6 min. ejjimo testas buvo vertinti prieš pradedant programą, po 16 ir po 32 savaičių. Nenustatyta jokių statistiškai reikšmingų skirtumų lyginant eisenos parametrus, gautus atliekant matavimus po 16 ir po 32 savaičių, tarp kontrolinès ir intervencinès grupių. Abiejose grupèse buvo gautas žymus per 6 min. nueito atstumo pailgejjimas, tačiau skirtumo tarp abiejų grupių nenustatyta. M. Fosdahl ir kolegų atliktas tyrimas atskleide, kad kombinuota 16 savaičių kineziterapijos programa, kurios metu buvo taikomi tempimo bei progresyviniai rezistenciniai pratimai, nepagerino vaikštančių, CP sergančių vaikų eisenos [16].

A. Bekius su kolegomis (2020) teigia, kad netaisyklinga eisena sergant CP gali būti iš dalies susijusi su ribota selektyvia motorine kontrole. Raumenų sinergijų analizè vis labiau naudojama pasikeitusios neuroraumeninès kontrolès vertinimui eisenos metu. Ankstyvas CP sergančių vaikų galvos smegenų pažeidimas gali lemti skirtingą raumenų sinergijų vystymąsi, lyginant su tipinès raidos vaikais, o tai gali apibūdinti nenormalius èjimo modelius. Autoriai teigia, kad būtina atlikti tolimesnius tyrimus šia tema tam, kad būtų galima išnagrinèti raumenų sinergijos panaudojimą kaip tikslą, kuriant naujas terapijas CP sergantiems vaikams [17]. X. Liang su bendraautoriais (2020) atliktoje sistemineje apžvalgoje teigia, kad fiziniai pratimai gali turèti teigiamą poveikị CP sergančių vaikų eisenos greičiui ir raumenų jègai, bet ne stambiosios motorikos funkcijai [18]. E. Swinnen ir kt. (2016) teigia, kad vaikams, sergantiems CP, būdinga laikysenos kontrolès disfunkcija bei patologiniai krūtinès ląstos ir dubens judesiai ir tai gali būti susiję su sumažejusiu dinaminiu stabilumu. Straipsnio autoriai išvadose pažymi, kad vaikams su bilateraliniu CP būdingos didesnès liemens amplitudès einant negu vaikams, kurie neserga CP. Šis judesių amplitudžių padidejjimas gali turèti neigiamą poveikị dinaminiam kūno stabilumui ejjimo metu. Hemipleginiu CP sergančių vaikų liemens judesių itaka dinaminiam stabilumui ne tokia akivaizdi ir reikalauja detalesnio ištyrimo [19]. E. Papageorgiou ir kolegos (2019) savo straipsnyje apžvelge CP sergančių vaikų klinikinių požymių ir eisenos nuokrypio sąsajas. Gautos išvados atskleidè, kad koreliacija tarp klinikinių simptomų ir eisenos nuokrypio buvo stipresnè bilateraline nei unilateraline $\mathrm{CP}$ forma sergančių vaikų. Be to, tyrimas irrode, kad galima nustatyti eisenos nuokrypio ir klinikinès išraiškos sąsajas identifikuojant atskiras eisenos ciklo fazes. Straipsnio autoriai teigia, kad šių žinių pritaikymas praktikoje galètų formuoti geresni supratimą apie eisenos sutrikimų patofiziologiją bei pagerinti individualaus gydymo plano sudarymą [6].
Funkcinè kineziterapija po selektyvinès miofasciotomijos (SM) gali pagerinti vaikų, sergančių CP eiseną bei apatinių galūnių jègą. V. Skoutelio ir kolegų (2018) atlikto tyrimo rezultatai parode, kad po SM ir funkcinès kineziterapijos žymiai pagerejo bendras eisenos grafiko nuokrypių indeksas (GGDI). Statistiškai patikimai po atliktų intervencijų padidejjo šlaunies lenkiamųjų, tiesiamujų, pritraukiamųų, kelio bei pėdos tiesiamujų raumenų vidutinè jèga. Tyrimo rezultatai parodè, kad statistiškai patikimai pagerèjo vaikų stambiosios motorikos funkcijos lygis (GMFCS) ir stambiosios motorikos jèga [20]. E. Shemy ir kolegos (2018) atliko tyrimą ir prièjo prie išvados, kad papildomi liemens stabilumo pratimai gali pagerinti vaikų, sergančių hemipleginiu $\mathrm{CP}$, liemens raumenų ištvermę bei eiseną [21]. Z. Hussein ir kt. (2019) teigia, kad vienu metu atliekama proprioceptinèvizualinè treniruote gali pagerinti erdvinius ir laiko eisenos parametrus, neturedama jokio poveikio spazminiu dipleginiu cerebriniu paralyžiumi sergančių vaikų kinetinès eisenos parametrams [22].

S. Chakraborty ir bendraautoriai (2020) atliko sisteminę apžvalgą ir išsiaiškino pagrindinius $\mathrm{CP}$ eisenai būdingus bruožus. Išanalizavę atliktus tyrimus, straipsnio autoriai teigia, kad netolygus poveikis sąnarių kinematikai anatominėse plokštumose patvirtina 3D eisenos analizès svarbą. Gautos išvados taip pat rodo, kad eisenos analizès rezultatams įtakos turi eisenos greitis tyrimo metu [23]. S. El-Shamy (2017) atliko tyrimą, kurio tikslas buvo išsiaiškinti antigravitacinès bėgimo takelio treniruotès ịtaką vaikų, sergančių dipleginiu $\mathrm{CP}$, eisenai, pusiausvyrai ir griuvimo rizikai. Buvo ištirta 30 dipleginiu CP sergančių vaikų, kurie atsitiktiniu būdu buvo suskirstyti ị tiriamają ir kontrolinę grupes. Tiriamoji grupe kartu su ịprastine kineziterapija papildomai atliko antigravitacinę treniruotę ant bėgimo takelio (po $20 \mathrm{~min}$. 3k./ sav.), kai kontrolinei grupei buvo taikytato paties dažnumo ịprastinè kineziterapija. Prieš intervenciją ir praejjus trims mènesiams buvo vertinti eisenos parametrai, laikysenos stabilumas, griuvimo rizika. Tyrimo rezultatai atskleide, kad žymus statistiškai reikšmingas visų parametrų pagerẻjimas gautas abiejose tyrimo grupèse. Vis delto didesnis eisenos parametrų (greičio, žingsnio ilgio, dažnio, atramos fazès trukmės) pagerejjimas pastebėtas tiriamojoje grupėje. Gauta išvada teigia, kad antigravitacinè bėgimo takelio treniruotė gali būti naudinga siekiant pagerinti eisenos parametrus, pusiausvyrą bei sumažinti kritimo riziką dipleginiu CP sergantiems vaikams [24]. A. Elnahhas ir kolegu (2019) atliktoje sistemineje apžvalgoje teigiama, kad trūksta aukštesnès kokybės tyrimu apie atbulinio ejimo treniruotès vaikams, sergantiems CP, teigiamą poveiki pusiausvyrai, stambiosios motorikos funkcijai, žingsnio ilgiui bei èjimo greičiui [25]. Be to, E. Papageorgiou ir bendraautoriu (2019) tyrimas 
ịrodè, kad galima nustatyti eisenos nuokrypio ir klinikinès išraiškos sąsajas, identifikuojant atskiras eisenos ciklo fazes. Straipsnio autoriai teigia, kad šių žinių pritaikymas praktikoje galètų formuoti geresni supratimą apie eisenos sutrikimų patofiziologiją bei pagerinti individualaus gydymo plano sudarymą [6].

\section{Išvados}

1. Vaikams, sergantiems CP, būdinga patologinè eisena lemia didesnes energijos sąnaudas, blogina judejjimo funkciją ir turi neigiamos įtakos kasdieniam aktyvumui.

2. Funkcinis eisenos treniravimas daro teigiamą poveiki ejjimo ištvermei bei su ejjimu susijusiai stambiajai motorikai, o eisenos treniruotė ant bėgtakio yra efektyvi priemone eisenos ištvermei, greičiui, galūnès palaikymo laikui, žingsnių dažniui bei ilgiui gerinti.

3. Raumenų jègos treniravimas gali turèti teigiamos ịtakos eisenos kinematikai, tačiau didžiausią įtaką tam turi greitis eisenos vertinimo metu.

4. Vikrumo lavinimas, elektromiografijos grižtamojo ryšio prietaiso naudojimas, viso kūno vibracija, virtuali realybė funkcinès eisenos treniruotès metu atskirose studijose taip pat turejjo teigiamą poveikị èjimo greičiui, tačiau reikalingi tolesni tyrimai.

5. Papildomi liemens stabilumo pratimai gali pagerinti vaikų, sergančių hemipleginiu $\mathrm{CP}$, liemens raumenų ištvermę bei eiseną.

6. Literatūroje trūksta duomenų apie kineziterapijos metodų poveikị atskiroms eisenos fazèms.

\section{Literatūra}

1. Domagalska-Szopa M, Szopa A. Gait pattern differences among children with bilateral cerebral palsy. Front Neurol 2019;10:183.

https://doi.org/10.3389/fneur.2019.00183

2. Gulati S, Sondhi V. Cerebral palsy: an overview. Indian J Pediatr 2018;85(11):1006-16.

https://doi.org/10.1007/s12098-017-2475-1

3. Hoffman RM, Corr BB, Stuberg WA, Arpin DJ, Kurz MJ. Changes in lower extremity strength may be related to the walking speed improvements in children with cerebral palsy after gait training. Res Dev Disabil 2018;73:14-20.

https://doi.org/10.1016/j.ridd.2017.12.005

4. Huang C, Chen Y, Chen G, Xie Y, Mo J, Li K, et al. Efficacy and safety of core stability training on gait of children with cerebral palsy. Medicine (Baltimore) 2020;99(2):e18609.

https://doi.org/10.1097/MD.0000000000018609

5. Collado-Garrido L, Paras-Bravo P, Calvo-Martin P, Santibanez M. [Impact of resistive therapy on gait parameters in children with cerebral palsy: systematic review and meta-analysis]. Rev
Neurol 2019;69(8):307-16.

6. Papageorgiou E, Simon-Martinez C, Molenaers G, Ortibus E, Van Campenhout A, Desloovere K. Are spasticity, weakness, selectivity, and passive range of motion related to gait deviations in children with spastic cerebral palsy? A statistical parametric mapping study. PLoS One 2019;14(10):e0223363. https://doi.org/10.1371/journal.pone.0223363

7. O'Brien SM, Lichtwark GA, Carroll TJ, Barber LA. Impact of lower limb active movement training in individuals with spastic type cerebral palsy on neuromuscular control outcomes: a systematic review. Front Neurol 2020;11:581892.

https://doi.org/10.3389/fneur.2020.581892

8. Oudenhoven LM, van Vulpen LF, Dallmeijer AJ, de Groot S, Buizer AI, van der Krogt MM. Effects of functional power training on gait kinematics in children with cerebral palsy. Gait Posture 2019;73:168-72.

https://doi.org/10.1016/j.gaitpost.2019.06.023

9. Galey SA, Lerner ZF, Bulea TC, Zimbler S, Damiano DL. Effectiveness of surgical and non-surgical management of crouch gait in cerebral palsy: a systematic review. Gait Posture 2017;54:93-105.

https://doi.org/10.1016/j.gaitpost.2017.02.024

10. Ito T, Noritake K, Sugiura H, Kamiya Y, Tomita H, Ito Y, et al. Association between gait deviation index and physical function in children with bilateral spastic cerebral palsy: a cross-sectional study. J Clin Med 2019;20;9(1):28.

https://doi.org/10.3390/jcm9010028

11. Moreau NG, Bodkin AW, Bjornson K, Hobbs A, Soileau M, Lahasky K. Effectiveness of rehabilitation interventions to improve gait speed in children with cerebral palsy: systematic review and meta-analysis. Phys Ther 2016;96(12):1938-54. https://doi.org/10.2522/ptj.20150401

12. Armand S, Decoulon G, Bonnefoy-Mazure A. Gait analysis in children with cerebral palsy. EFORT Open Rev 2016;1(12):448-60.

https://doi.org/10.1302/2058-5241.1.000052

13. Han Y-G, Yun C-K. Effectiveness of treadmill training on gait function in children with cerebral palsy: meta-analysis. J Exerc Rehabil 2020;16(1):10-9.

https://doi.org/10.12965/jer.1938748.374

14. Booth ATC, Buizer AI, Meyns P, Oude Lansink ILB, Steenbrink F, van der Krogt MM. The efficacy of functional gait training in children and young adults with cerebral palsy: a systematic review and meta-analysis. Dev Med Child Neurol 2018;60(9):866-83.

https://doi.org/10.1111/dmcn.13708

15. Matsunaga N, Ito T, Noritake K, Sugiura H, Kamiya Y, Ito Y, Mizusawa J, Sugiura H. Correlation between the Gait Deviation Index and skeletal muscle mass in children with spastic cerebral palsy. J Phys Ther Sci 2018;30(9):1176-1179.

https://doi.org/10.1589/jpts.30.1176 
16. Fosdahl MA, Jahnsen R, Kvalheim K, Holm I. Effect of a combined stretching and strength training program on gait function in children with cerebral palsy, GMFCS level I \& II: a randomized controlled trial. Medicina (Kaunas) 2019;55(6):250. https://doi.org/10.3390/medicina55060250

17. Bekius A, Bach MM, van der Krogt MM, de Vries R, Buizer AI, Dominici N. Muscle synergies during walking in children with cerebral palsy: a systematic review. Front Physiol 2020;11:632. https://doi.org/10.3389/fphys.2020.00632

18. Liang X, Tan Z, Yun G, Cao J, Wang J, Liu Q, et al. Effectiveness of exercise interventions for children with cerebral palsy: a systematic review and meta-analysis of randomized controlled trials. J Rehabil Med 2020 Nov 23.

https://doi.org/10.2340/16501977-2772

19. Swinnen E, Goten LV, De Koster B, Degelaen M. Thorax and pelvis kinematics during walking, a comparison between children with and without cerebral palsy: a systematic review. NeuroRehabilitation 2016;38(2):129-46.

https://doi.org/10.3233/NRE-161303

20. Skoutelis VC, Kanellopoulos A, Vrettos S, Gkrimas G, Kontogeorgakos V. Improving gait and lower-limb muscle strength in children with cerebral palsy following selective percutaneous myofascial lengthening and functional physiotherapy. NeuroRehabilitation 2018;43(4):361-8. https://doi.org/10.3233/NRE-182468

21. Shemy E, Attia S. Trunk endurance and gait changes after core stability training in children with hemiplegic cerebral palsy: a randomized controlled trial. J Back Musculoskelet Rehabil 2018;31(6):1159-67.

https://doi.org/10.3233/BMR-181123

22. Hussein ZA, Salem IA, Ali MS. Effect of simultaneous proprioceptive-visual feedback on gait of children with spastic diplegic cerebral palsy. J Musculoskelet Neuronal Interact 2019;19(4):500-6.

23. Chakraborty S, Nandy A, Kesar TM. Gait deficits and dynamic stability in children and adolescents with cerebral palsy: a systematic review and meta-analysis. Clin Biomech Bristol Avon 2020;71:11-23. https://doi.org/10.1016/j.clinbiomech.2019.09.005

24. El-Shamy SM. Effects of antigravity treadmill training on gait, balance, and fall risk in children with diplegic cerebral palsy. Am J Phys Med Rehabil 2017;96(11):809-15. https://doi.org/10.1097/PHM.0000000000000752

25. Elnahhas AM, Elshennawy S, Aly MG. Effects of backward gait training on balance, gross motor function, and gait in children with cerebral palsy: a systematic review. Clin Rehabil 2019;33(1):3-12.

https://doi.org/10.1177/0269215518790053

\section{EFFECTS OF DIFFERENT REHABILITATION METHODS ON CHILDREN WITH CEREBRAL PALSY, MOTOR FUNCTIONS AND GAIT \\ G. Juškėnienė, A. Šidlauskienė, J. Raistenskis, J. Žižienè, K. Daunoravičienè}

Keywords: children, cerebral palsy, gait analysis, motor functions.

Summary

Cerebral palsy (CP) is caused by developing brain damage and comprises a group of permanent disorders of movement and postural development that cause daily activity limitations [1,2]. This disease has a high probability of resulting in lower extremity strength and walking deficits $[3,4]$. CP is one of the main causes of disability in childhood [5]. Physiotherapy is a chief component of rehabilitation for children with $\mathrm{CP}$, correcting gait and improving capacity of walking through muscle strength training. The problem is that the standard rehabilitation programs for CP have not been determined yet [4]. The literature indicates that relationships between clinical impairments and gait deviations in children with CP can be determined by identifying specific parts of the gait cycle. Integration of these findings could lead to a better understanding of the pathophysiology of gait deviations and, eventually, support individualized treatment planning [6].

Correspondence to: giedre.juskeniene@santa.lt

Gauta 2021-03-05 